\title{
Influence of Cowpea and Soybean Intercropping Pattern and Time of Planting on Yield and Gross Monetary Value of Sorghum
}

\author{
Kinde Lamessa ${ }^{1^{*}}$, Sharma J.J ${ }^{2}$ and Taye Tessema ${ }^{3}$ \\ ${ }^{1}$ Oromia Agricultural Research Institute (OARI), Mechara Agricultural Research Center (McARC), \\ P.O. Box: 19: Mechara, Ethiopia \\ ${ }^{2}$ School of Plant Sciences, Haramaya University,P.O.Box:138, Dire Dawa, Ethiopia \\ ${ }^{3}$ Ethiopia Institute of Agriculture Research (EIAR), P.O.Box: 2003: Addis Ababa, Ethiopia
}

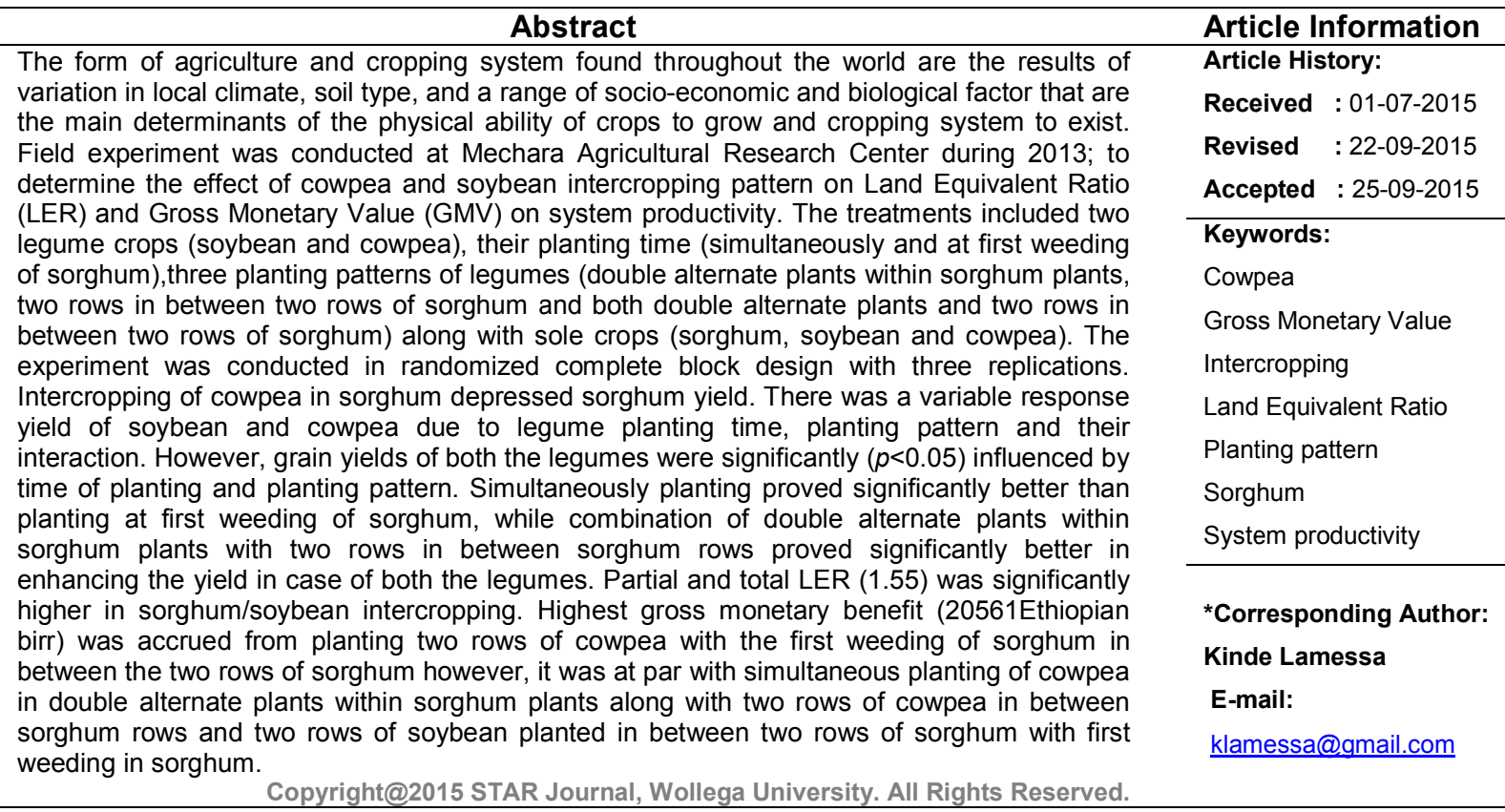

\section{INTRODUCTION}

The current challenge of many developing countries is to produce and more and more necessities namely food, fodder, fuel and fiber forever-increasing human population. On the limited available land. Nearly $90 \%$ of the food requirements will have to come from land-based farming (Darshan, 2008).

One of the most important strategies to increases agricultural output is the development of new high intensity cropping systems, including intercropping system, which are resistant to biotic and abiotic stresses using soil building, protein containing and high yielder crops.

The cropping system is defined as the combination of crops grown on a given area within year. The form of agriculture and cropping system found throughout the world are the results of variation in local climate, soil type, and a range of socio-economic and biological factor that are the main determinants of the physical ability of crops to grow and cropping system to exist. Therefore, cropping system varies from location to location (Seran and Brintha, 2010).

Cropping system researcher is attracting worldwide attentions both in developed and in developing countries. Temporal and spatial intensification of crops constitutes the basic ingredients of national food production strategy. It helps to create varied income sources and labor use distribution. The economic return or monetary gain per unit area and time are the major considerations for adoptions of a certain cropping system and yield is the foremost agronomic parameter to compare the importance of component crops in any type of cropping system. Soil fertility, temperature, length of rainy season 
Kinde Lamessa et al.,

and pressure on the land influence the type of cropping systems used by smallholders.

In general, in designing alternative crop systems, the common approaches to be followed are crop intensification, crop diversification and cultivar options. However, the three approaches become inseparable and considered as a building block of a new system (Yadav et al., 1998).

Intercropping defined as the growing of two or more crops simultaneously in the same field, thus resulting in crop intensification in time and space. The main objective of intercropping has been to maximize use of resources, such as space, light and nutrients as well as to improve forage quality and quantity. Most researchers believe that intercropping system is especially beneficial to the smallholder farmers in the low-input and high-risk environments of the tropics (Rana et al., 2001). The principal reasons for smallholder farmers to intercrop are flexibility, profit maximization, risk minimization against total crop failure, soil conservation and improvement of soil fertility, weed management and balanced nutrition (Shetty et al., 1995). Intercrop can give higher yield than sole crop yields, greater yield stability, more efficient use of nutrients, better weed management, provision of insurance against total crop failure, improved quality by variety, also cereal as a sole crop requires a larger area to produce the same yield as cereal in an intercropping system (Jensen, 1996).

In Ethiopia, sorghum was cultivated on 1.78 million hectare with a production of 3.47 million metric tons and the average yield of 1.95 ton ha $^{-1}$ during 2010-2011 (CSA, 2012). The livelihood millions of Ethiopians depends on this staple food crop. It remains to be primary source of food in Ethiopia (Asfaw, 2007). Besides, it has tremendous uses for the Ethiopia farmers and no parts of the plant are ignored. Sorghum is a major food crop grown in Western Hararghe, accounting for 59.3\%
Sci. Technol. Arts Res. J., July-Sep 2015, 4(3): 38-46

followed by maize $32.8 \%$, and tef $4.15 \%$ of the total cultivated areas (CSA, 2012).

In both West Hararghe and Eastern Hararghe chat/sorghum, chat/maize, chat/sweet potato, sorghum/ legumes and maize/legumes the common type intercropping system practiced by farmers. However, research on time of planting and planting pattern of soybean and cowpea on yield and gross monetary value of sorghum has not been carried out in West Hararghe. Therefore, the study was conducted with the following objectives: To determine the effect of cowpea and soybean intercropping pattern on Land Equivalent Ratio (LER) and Gross Monetary Value (GMV) on system productivity.

\section{MATERIALS AND METHODS}

\section{Location of Study Area}

The field experiment was conducted at Mechara Agricultural Research Center (McARC) during the 2013 cropping season. McARC is found at an Altitude of 1700 m.a.s.l at $40^{\circ} 19^{\prime}$ North latitude and $08^{\circ} 35^{\prime}$ East longitude. The major soil type of the center is sandy clay with reddish color (McARC, 2010). McARC is located at Daro Labu, which is one of the districts of West Hararghe Zone, Oromia Regional State of Ethiopia and $12 \%$ of its area lies in the high land, $44 \%$ in the mid-high land and $44 \%$ in the low land agro ecological zones. The rainfall in this area is usually erratic; there is also rainfall variability in the onset and cessation of the main rainfall. Farming systems of Daro Labu district constitute complex production units involving a diversity of interdependent mixed cropping and livestock activities. The area is predominantly cereal producing with sorghum and maize as staple food crops; the major annual crops grown include sorghum, maize, groundnuts, sweet potato, wheat, common beans and barley. In addition, the major cash crops, like chat and coffee, have a long-standing tradition in the district.

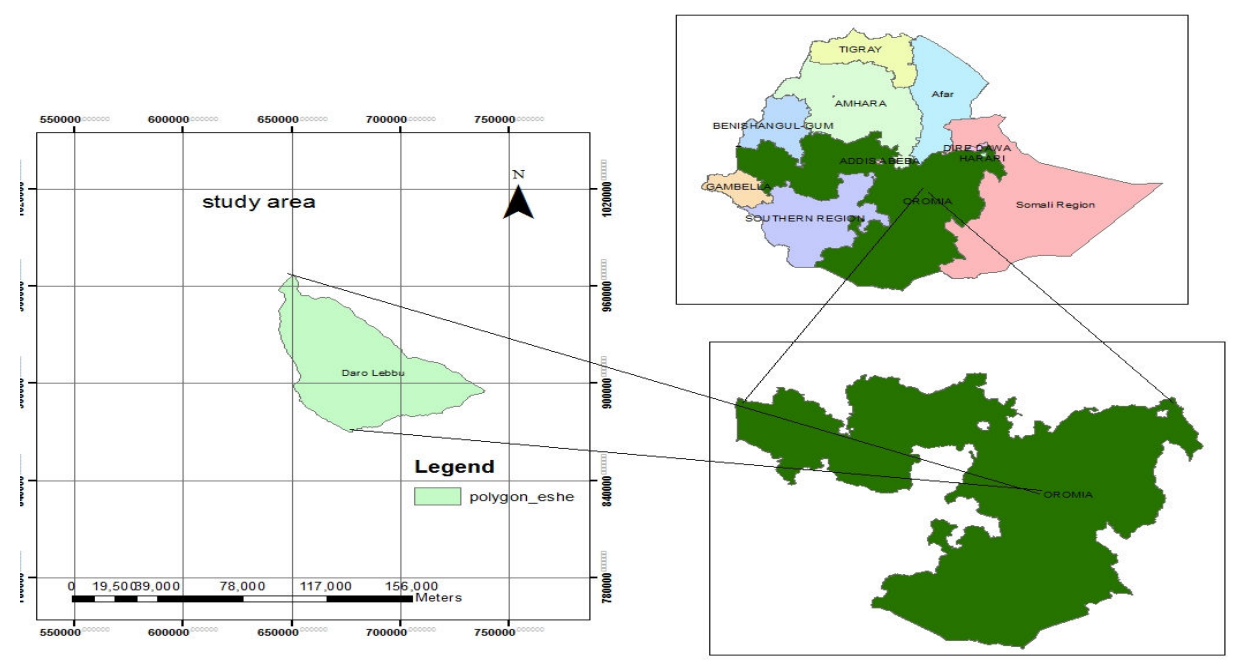

Figure 1: Map of the study area

Monthly data of total rainfall, maximum and minimum temperatures during the experimental season (JuneNovember) showed a total rainfall of $757.6 \mathrm{~mm}$ out of which $35.1 \%$ was received during the month of August. Mean monthly maximum and minimum temperatures of the experimental season varied between $24.88^{\circ} \mathrm{C}$ and $26.68^{\circ} \mathrm{C}$ and $14.95^{\circ} \mathrm{C}$ to $15.35^{\circ} \mathrm{C}$, respectively while the average temperature during the cropping season was $20.45^{\circ} \mathrm{C}$. In general, the average monthly maximum and minimum temperatures and rainfall distribution were suitable for sorghum production. 


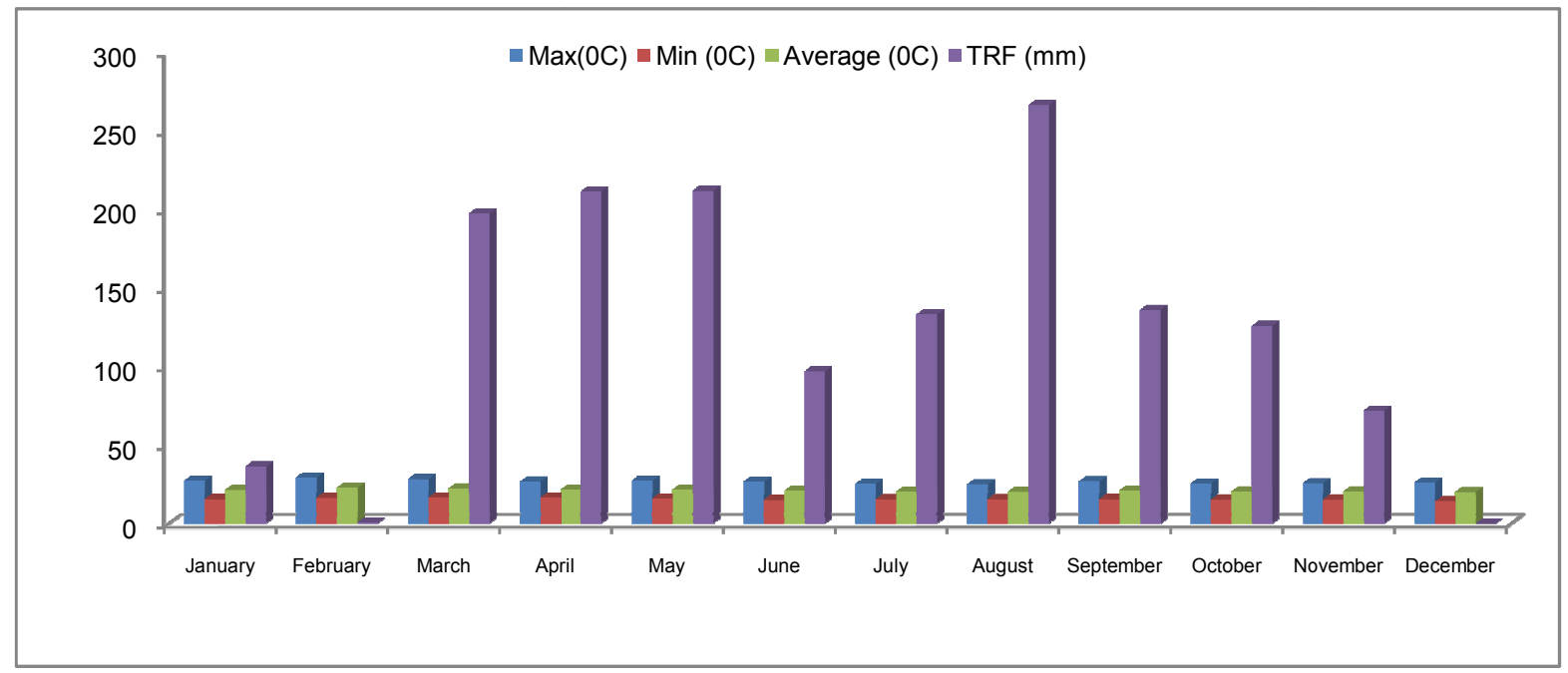

Figure 2: Weather data of 2013 cropping season (Source: Mechara weather station)

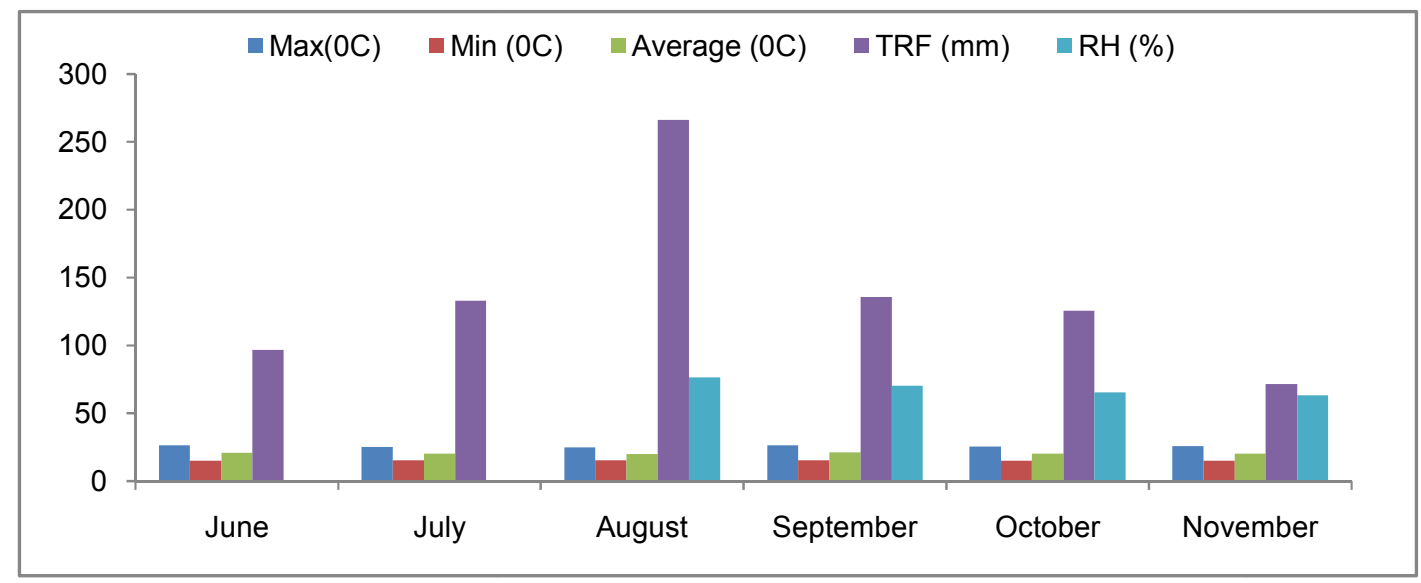

Figure 3: Weather data of experimental season

\section{Experimental Materials}

Sorghum variety Girana-1, cowpea variety ILRI11114accession number and soybean variety Crowford were used for the study.

\section{Treatments and Experimental Design}

Cowpea and soybean were intercropped with sorghum in three planting patterns, i.e. inter rows (two rows each of cowpea and soybean in between two rows of sorghum) and intra-rows (two plants each of soybean and cowpea in between two sorghum plants) and the combination of both inter and intra rows. The legume intercrops were planted as per their planting pattern simultaneously with sorghum and at the time of first hand weeding sorghum. Thus, there were 12 treatment combinations (two legume crops $x$ three planting patterns $x$ two time of planting). Apart from these treatments, sole sorghum, sole cowpea and soybean were used for the study. The experiment was laid out in a randomized complete block design (RCBD) in a factorial arrangement with three replications. $1 \mathrm{~m}$ and each block with $1.5 \mathrm{~m}$ separated each plot. The plot size was $4.5 \mathrm{~m} \times 3.0 \mathrm{~m}=13.5 \mathrm{~m}^{2}$. The net plot size was $3.0 \mathrm{~m}$ $x 1.8 \mathrm{~m}$. The sole and intercropped sorghum were planted in spacing of $75 \mathrm{~cm} \times 30 \mathrm{~cm}$ with a population density of $44,444 \mathrm{ha}^{-1}$. Sorghum seed was drilled in the rows and thinned to the recommended spacing at $30 \mathrm{~cm}$ between plants. Both cowpea and soybean were spaced at 18.75 $\mathrm{cm}$ from the sorghum rows with intra-row spacing of 10 $\mathrm{cm}$ and $5 \mathrm{~cm}$ for cowpea and soybean, respectively. The inter row spacing of $37.5 \mathrm{~cm}$ was between the rows of legume crops. The populations of cowpea and soybean were $2,66,666$ and 5, 33,333 ha $^{-1}$, respectively. In intra, rows of sorghum two seeds of both soybean and cowpea were spaced $10 \mathrm{~cm}$ from each sorghum plant. The population of sole cowpea and soybean in combined interand intra-row planting pattern 33, 3332 and 59, $9999 \mathrm{ha}^{-1}$, respectively. The sole soybean and cowpea were planted at recommended spacing of $60 \mathrm{~cm} \times 5 \mathrm{~cm}$ and $60 \mathrm{~cm} \times 10$ $\mathrm{cm}$ with a population of $3,33,333$ and $1,66,666 \mathrm{ha}^{-1}$, respectively. Simultaneously planting of sorghum and legume crops was made on 24 June 2013 and the sowing of legume crop at first weeding of sorghum was done on 28 July 2013. After the crop emerged, thinning was carried out according to recommended population and spacing for all crops. Land Equivalent Ratio (LER) was calculated to determine the productivity of the system as proposed by Willey (1979).

$$
\mathrm{LER}=\mathrm{Yab} / \mathrm{Yaa}+\mathrm{Yba} / \mathrm{Ybb}
$$

Where; $Y$ is the yield per unit area, $Y a b$ and $Y b a$ are intercrop yields of the component crops $a$ and $b$ respectively and $\mathrm{Yaa}$ and $\mathrm{Ybb}$ are sole crop yields of a and $b$ respectively. Gross Monetary Value (GMV) was 
Kinde Lamessa et alo,

determined to evaluate the economic advantage of intercropping system as compared to sole cropping (Willey, 1979). GMV was computed from the yield of sorghum, and soybean and cowpea component crops by multiplying the yields with their respective unit price. The total value obtained from the component crops were used to indicate the Gross Monetary Value. To estimate the GMV of component crops, sorghum grain yield was valued at an average open market price of $7.00 \mathrm{ETB} \mathrm{kg}^{-1}$, soybean and cowpea each at 4 ETB kg-1 at the time of crop harvest in Daro Labu District, West Hararghe.

\section{Data Analysis}

The analysis of variance (ANOVA) was carried out using statistical packages and procedures out lined by Gomez and Gomez (1984) appropriate to Randomized
Sci. Technol. Arts Res. J., July-Sep 2015, 4(3): 38-46

Complete Block Deign using GenStat Computer Software version 13.3. Mean separations was carried out using least significant difference (LSD) at $5 \%$ probability level.

\section{RESULTS}

Soil Analysis : The soil analysis data indicated that the soil of the study area had low $(0.2 \%)$ level of total nitrogen, $(2.73 \%)$ medium level of organic carbon, (3.46ppm) low level of available phosphorus, and medium CEC $(21.6 \mathrm{meq} / 100 \mathrm{~g})($ Table 1$)$. The $\mathrm{pH}\left(\mathrm{H}_{2} \mathrm{O}\right)$ of the soil was 5.63 showing moderately acidic nature of the soil Thus, the $\mathrm{pH}$ of the experimental soil was within the range for productive soils. Soil textural analysis results indicated that the textural class of the experimental site was sandy clay.

Table 1: Selected physicochemical properties of experimental field soil before planting

\begin{tabular}{|c|c|}
\hline Soil proprieties & Value \\
\hline $\mathrm{pH}\left(1: 2: 5 \mathrm{H}_{2} \mathrm{O}\right)$ & 5.63 \\
\hline Organic carbon (\%) & 2.73 \\
\hline Total nitrogen (\%) & 0.2 \\
\hline Available phosphorus (ppm) & 3.46 \\
\hline Cation exchange capacity (meq/100g) & 21.6 \\
\hline \multicolumn{2}{|c|}{ Particle size distribution } \\
\hline Sand & $51 \%$ ( very high level sand) \\
\hline Clay & $34 \%$ ( Moderate level of clay) \\
\hline Slit & $15 \%$ (low Level of slit ) \\
\hline
\end{tabular}

Grain Yield of Sorghum: Sorghum grain yield was significantly $(p<0.05)$ influenced due to main effect of legume crops, time of planting, planting pattern and all interaction effects; except the interaction of legume crops with time of planting.

Cowpea Grain Yield: Grain yield of cowpea was highly and significantly $(p<0.01)$ influenced by the main effect of time of planting and planting pattern. Interaction effect of time of planting and planting pattern was not significant.

Soybean Grain Yield: The analysis of variance showed that grain yield of soybean had highly significant $(p<0.01)$ difference due to main effect of time of planting and planting pattern while their interaction had no significant difference (Table 2).

Table 2: Main effect of legume crops, time of planting and planting patterns on yield of sorghum, cowpea and soybean in sorghum intercropped with cowpea and soybean

\begin{tabular}{|c|c|c|c|}
\hline Treatments & $\begin{array}{l}\text { Sorghum } \\
\text { yield kg ha }\end{array}$ & $\begin{array}{l}\text { Cowpea } \\
\text { yield kg ha }\end{array}$ & $\begin{array}{l}\text { Soybean } \\
\text { yield kg ha }\end{array}$ \\
\hline \multicolumn{4}{|l|}{ Legumes (L) } \\
\hline Soybean & 1787.1 & & \\
\hline Cowpea & 1401.8 & & \\
\hline LSD (\%) & 77.85 & & \\
\hline \multicolumn{4}{|l|}{ Time of planting (TP) } \\
\hline Simultaneously & 1436.1 & 1863.3 & 1169.0 \\
\hline First hand weeding & 1752.8 & 1517.2 & 921.0 \\
\hline LSD (\%) & 77.85 & 102.01 & 117.7 \\
\hline \multicolumn{4}{|l|}{ Planting pattern (PP) } \\
\hline Double alternate plant & 1535.2 & 1505.4 & 735.0 \\
\hline Two rows of inter crops & 1755.0 & 1764.6 & 1169 \\
\hline Two rows of inter crops + DAPs & 1493.2 & 1800.9 & 1229 \\
\hline LSD (5\%) & 95.37 & 124.93 & 144.2 \\
\hline CV (\%) & 7.1 & 5.7 & 10.7 \\
\hline LXPP & * & & \\
\hline LXTP & NS & & \\
\hline TPXPP & * & NS & NS \\
\hline LXPPXTP & * & & \\
\hline
\end{tabular}




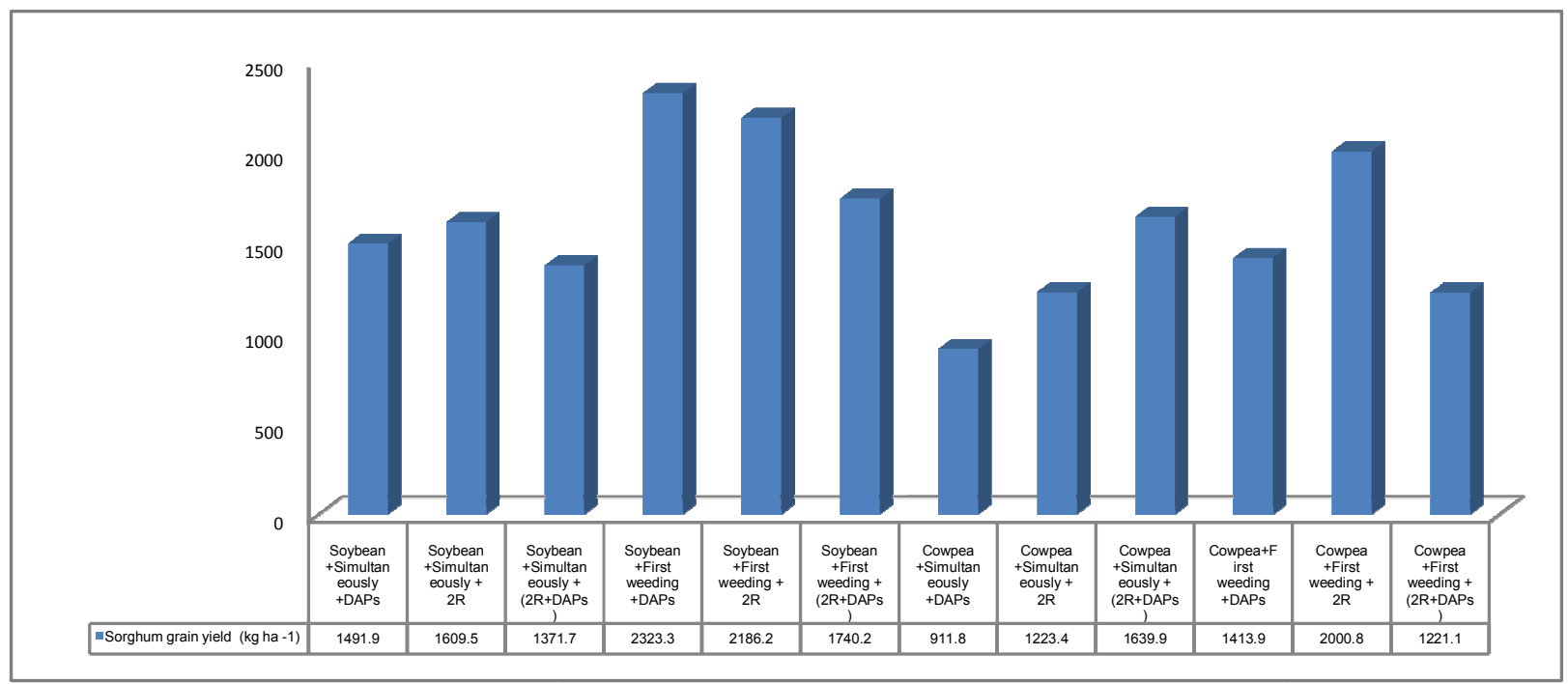

Figure 4. Grain yield of sorghum as affected by soybean and cowpea intercropping system

Table 3: Interaction effect of time of planting and planting pattern on grain yield of cowpea, in cowpea intercropped with sorghum

\begin{tabular}{lccc}
\hline & \multicolumn{3}{c}{ Cowpea grain yield kg ha $^{-1}$} \\
\cline { 2 - 4 } Time of planting & DAPs & 2R & 2R+DAPs \\
\hline Simultaneously & 1720.2 & 1890.2 & 1979 \\
First weeding & 1290.5 & 1638.9 & 1622 \\
\hline LSD (5\%) & \multicolumn{3}{|c}{$\mathbf{1 7 6 . 6 8}$} \\
CV (\%) & \multicolumn{3}{c}{$\mathbf{5 . 7 0}$} \\
\hline LSD= Least significant difference, CV= Coefficient of variation
\end{tabular}

Table 4: Main effect of legume crops, time of planting and planting pattern on sorghum and legumes partial land equivalent ratios and total land equivalent ratio in sorghum intercropped with cowpea and soybean

\begin{tabular}{|c|c|c|c|}
\hline Treatments & $\begin{array}{l}\text { Sorghum } \\
\text { partial LER }\end{array}$ & $\begin{array}{l}\text { Legumes } \\
\text { partial LER }\end{array}$ & $\begin{array}{l}\text { Total } \\
\text { LER }\end{array}$ \\
\hline \multicolumn{4}{|l|}{ Legumes (L) } \\
\hline Soybean & 0.767 & 0.785 & 1.55 \\
\hline Cowpea & 0.605 & 0.584 & 1.19 \\
\hline LSD (5\%) & 0.072 & 0.0985 & 0.124 \\
\hline \multicolumn{4}{|c|}{ Time of planting(TP) } \\
\hline Simultaneously & 0.609 & 0.753 & 1.36 \\
\hline First weeding & 0.763 & 0.616 & 1.38 \\
\hline LSD (5\%) & 0.072 & 0.0985 & NS \\
\hline \multicolumn{4}{|c|}{ Planting pattern (PP) } \\
\hline DAPs & 0.655 & 0.709 & 1.21 \\
\hline $2 \mathrm{R}$ & 0.765 & 0.793 & 1.47 \\
\hline $2 \mathrm{R}+\mathrm{DA}$ & 0.638 & 0.552 & 1.43 \\
\hline LSD (5\%) & 0.0878 & 0.1207 & 0.151 \\
\hline CV (\%) & 15.1 & 20.8 & 13 \\
\hline \multicolumn{4}{|c|}{ Cropping system } \\
\hline Intercropped & & & 1.37 \\
\hline Sole sorghum & & & 1.00 \\
\hline Sole cowpea & & & 1.00 \\
\hline Sole soybean & & & 1.00 \\
\hline $\begin{array}{l}\text { LSD (5\%) } \\
\text { CV (\%) }\end{array}$ & & & $\begin{array}{l}0.366 \\
21.3\end{array}$ \\
\hline LXTP & NS & NS & NS \\
\hline LXPP & * & NS & NS \\
\hline TPXPP & ** & NS & * \\
\hline LXTPXPP & NS & NS & NS \\
\hline
\end{tabular}


Kinde Lamessa et alo,

Land Equivalent Ratio (LER): The total land equivalent ratios (LER) were obtained by summing up the partial land equivalent ratios of sorghum and legume crops. Sorghum and legume partial land equivalent ratios were significantly $(p \leq 0.05)$ affected due to main effect of legume crops, time of planting, planting pattern and the
Sci. Technol. Arts Res. J., July-Sep 2015, 4(3): 38-46

interaction of legumes with planting pattern (Table 5). In addition, sorghum partial LER was also influenced by legume planting patterns and time of planting. Partial land equivalent ratios for the crops in intercropping systems were less than one and unity.

Table 5: Main effect of legume crops, time of planting and planting patterns on GMV in sorghum intercropped with cowpea and soybean

\begin{tabular}{|c|c|c|c|}
\hline Treatments & $\begin{array}{l}\text { Sorghum } \\
\left(\text { Birr ha }^{-1}\right)\end{array}$ & $\begin{array}{l}\text { Legumes } \\
\left(\text { Birr ha }^{-1}\right)\end{array}$ & $\begin{array}{l}\text { GMV } \\
\left(\text { Birr ha }^{-1}\right)\end{array}$ \\
\hline \multicolumn{4}{|l|}{ Legumes } \\
\hline Soybean & 12510 & 4178 & 16688 \\
\hline Cowpea & 9813 & 6761 & 16574 \\
\hline LSD (5\%) & 545.1 & 324.8 & NS \\
\hline \multicolumn{4}{|c|}{ Time of planting } \\
\hline Simultaneously & 10053 & 6064 & 16117 \\
\hline First weeding & 12270 & 4876 & 17146 \\
\hline LSD (5\%) & 545.1 & 324.8 & 571.9 \\
\hline \multicolumn{4}{|c|}{ Planting pattern } \\
\hline DAPs & 10747 & 4481 & 15228 \\
\hline $2 \mathrm{R}$ & 12285 & 5868 & 18153 \\
\hline $2 \mathrm{R}+\mathrm{DAPs}$ & 10453 & 6060 & 16513 \\
\hline LSD (5\%) & 667.6 & 397.8 & 700.4 \\
\hline CV (\%) & 7.1 & 8.6 & 5.0 \\
\hline \multicolumn{4}{|c|}{ Cropping system } \\
\hline Intercropped & & & 16631 \\
\hline Sole sorghum & & & 16440 \\
\hline Sole cowpea & & & 11675 \\
\hline Sole soybean & & & 5386 \\
\hline LSD (5\%) & & & 2992 \\
\hline CV (\%) & & & 15.8 \\
\hline LXTP & NS & NS & NS \\
\hline LXPP & $* *$ & NS & $* *$ \\
\hline TPXPP & $* *$ & NS & $* *$ \\
\hline LXTPXPP & $*$ & NS & * \\
\hline
\end{tabular}

Gross Monetary Value (GMV): GMV was also used to evaluate economic advantages of intercropping system. As result of economic analysis, intercropping of soybean and cowpea with sorghum was more advantageous than sole cropping sorghum. GMV was significantly $(p \leq 0.05)$ affected due to main effect of time of planting and planting patterns but not due to the main of effect of legume crops (Table 6).

Table 6: Interaction effect of legume crops, time of planting and planting pattern on GMV of sorghum, in cowpea and soybean cropping system

\begin{tabular}{lllll}
\hline & & \multicolumn{3}{c}{ GMV } \\
\hline \multirow{2}{*}{ Legumes crops } & & \multicolumn{3}{c}{ Planting pattern } \\
\cline { 3 - 5 } Soybean with sorghum & Time of planting & DAPs & 2R & 2R+DAPs \\
& Simultaneously & $14086 \mathrm{fg}$ & $16259 \mathrm{de}$ & $17569 \mathrm{~cd}$ \\
Cowpea with sorghum & First weeding & $18503 \mathrm{bc}$ & $19666 \mathrm{ab}$ & $14046 \mathrm{fg}$ \\
& Simultaneously & $13264 \mathrm{~g}$ & $16125 \mathrm{e}$ & $19397 \mathrm{ab}$ \\
& First weeding & $15059 \mathrm{ef}$ & $20561 \mathrm{a}$ & $15036 \mathrm{ef}$ \\
\hline LSD (5\%) & & \multicolumn{3}{c}{$\mathbf{1 4 0 0 . 9}$} \\
CV (\%) & & $\mathbf{5 . 0 0}$ \\
\hline
\end{tabular}

$\mathrm{LSD}=$ Least significant difference; $\mathrm{CV}=$ Coefficient of variation

\section{DISCUSSION}

The interaction of three factors revealed that soybean DAPs at the time of sorghum first weeding resulted in the highest grain yield of sorghum; however, it did not show significant difference with soybean planted in $2 \mathrm{R}$ in between two sorghum rows at first weeding. The (911.8 $\mathrm{kg} \mathrm{ha}^{-1}$ ) lowest grain yield of sorghum was obtained when cowpea was intercropped in DAPs simultaneously with sorghum.

Soybean intercropped with sorghum resulted in significantly lower grain yield when planted simultaneously with sorghum than planting at first weeding of sorghum under all the planting patterns. On the other hand, 
Kinde Lamessa et alo,

cowpea-sorghum intercropping showed, a similar trend except cowpea planted with first weeding in sorghum in $2 \mathrm{R}+\mathrm{DAPs}$ pattern, where in simultaneous planting in 2R+DAPs pattern gave significantly higher grain yield (Table 3). Myaka and Kabbissa (1996) and Champion et al. (1998) reported that variation in planting pattern could cause variation in nutrient uptake and the general performance of intercropping system.

Addo-Quaye (2011) found that time of introduction of soybean significantly affected maize grain yield and delayed soybean planting increased maize grain yield in maize/soybean cropping system. It was also reported that maize planted in alternate rows 28 days after soybean gave significantly higher grain yield than those planted in double rows of soybean. Similarly, Chemeda (1997) reported that delayed bean planting increased maize grain yield in maize / bean cropping systems. Fasil and Verkleij (2007) also reported that sorghum/ soybean-cropping system reduced sorghum yield by $27.5 \%$ while in system the magnitude of sorghum yield reduction was $55.6 \%$ sorghum/cowpea intercropping. Similarly, Oseni and Aliyu (2010) obtained a reduction of $69.7 \%$ in sorghum yield due to sorghum/cowpea intercropping. Further, they found that grain yield of sorghum was higher in sole cropping than intercropping mixtures. This was in agreement with the findings of Langat et al. (2006) who indicated that intercropping significantly affected the yield of sorghum in sorghum/ groundnut intercropping. Other studies revealed higher sorghum (Tamado and Eshetu, 2000) and maize (Chemeda, 1997) grain yield in sole cropping than intercropping. The interaction effect of legume, their planting time and planting pattern showed that planting of soybean in double alternate plants in between sorghum plants at the first weeding of sorghum resulted in a significant increase in sorghum yield over other interaction except the interaction of two soybean rows planted at the first weeding of sorghum in between two sorghum rows. Further, the latter interaction was statistically in parity with the interaction of two rows of cowpea planted at first weeding in sorghum. Simultaneous planting of double plants of cowpea in between the sorghum plants resulted in significant decrease in sorghum yield over other interactions.

Highest grain yield of soybean (1169 kg ha-1) was recorded when soybean was planted simultaneously with sorghum, which was $26.9 \%$ higher than the yield obtained when soybean was planted with first weeding of sorghum. Sowing date is one of the most important agronomic factors affecting grain yield of soybean in intercropping system. Grain yield of soybean decreased with delayed sowing. Therefore, simultaneously planting with sorghum resulted in higher soybean grain yield. The reduction in grain yield of soybean by intercropping could be due to interspecific competition and depressive effect of sorghum, a $\mathrm{C}_{4}$ species on soybean, a $\mathrm{C}_{3}$ crop. Although the sorghum growth rate may be less than soybean at the initial stage (30-40) days after. Sowing, both crops attained the peak growth rate at 60-70 days after sowing. Due to the above reason, soybean yield decreased when planted at the first weeding of sorghum. This is in agreement with the findings of Chemeda (1997) who obtained higher haricot bean yield when the haricot bean cultivars were planted simultaneously with maize than common bean Nnoko and Doto (1980) reported that planting soybean before cereal gave significantly higher yield than planting soybean at the same time or after the
Sci. Technol. Arts Res. J., July-Sep 2015, 4(3): 38-46

cereal. Addo-Quaye et al. (2011) also showed that soybean planted before maize (maize planted 14 days after soybean, maize planted 28 days after soybean) recorded higher grain yield than soybean planted after maize. Different planting patterns of soybean intercropped with sorghum significantly the grain yield of soybean. A combination of two rows of soybean in between sorghum rows (2R) and double alternate plants within sorghum plants (DAPs) resulted in the highest soybean yield, which was statistically at par with the grain yield obtained in two rows of soybean intercropped in between sorghum rows. However, both these planting patterns resulted in significantly higher grain yield than double alternate soybean plants within sorghum plants. this yield increase was 67.2 and $59.0 \%$ respectively with two rows of soybean in between sorghum rows plus double alternate plants within sorghum plants (2R+DAPs) and two rows of soybean intercropped in between sorghum rows (2R) over double alternate soybean plants (DAPs) and two rows of soybean intercropped in between sorghum rows (2R) over double alternate soybean plants (DAPs) within sorghum plants. cropping system did not significant influence soybean grain yield in sorghum / soybean cropping system.

The highest cowpea yield (1979.5 kg ha-1) was obtained when it was planted simultaneously with sorghum in two rows of cowpea in between sorghum rows along with double alternate plants of cowpea within sorghum plants (2R+DAPs). The yield obtained with this interaction was significantly higher than the other interactions except the interaction of simultaneous planting of cowpea in $2 \mathrm{R}$ pattern in between sorghum rows. The cowpea yield was significantly reduced when planted at the first weeding of sorghum under all the planting patterns compared to simultaneous planting of cowpea with sorghum. The data also showed that cowpea planted at the first weeding in DAPs resulted in significant reduction in yield compared to other interactions. This was in agreement with the findings of Gandebe et al. (2010) where reported that the time of introducing cowpea into maize significantly affected the yield of cowpea; simultaneous planting showed increasing cowpea yield when compared to introducing cowpea into maize when delayed by two or four weeks. When comparing the sole and intercropped cowpea yield, it was observed that sole cropping system gave $2918.3 \mathrm{~kg}$ ha- 1 cowpea yield that was $72.6 \%$ higher than the intercropped cowpea yield. Similarly, Oseni and Aliyu (2010) reported a 55.3\% cowpea yields reduction due to sorghum/ cowpea intercropping system. Oseni (2010) also found that grain yield of cowpea was higher in sole cropping than in intercropping mixtures. This was in agreement with the findings of Egbe et al. (2010) who found that cowpea grain yield was depressed by maize-cowpea intercropping systems. In this present study, not only the yield of cowpea was depressed by sorghum but cowpea also depressed the yield of sorghum.

Higher total LER (1.55) was obtained from sorghum/ soybean than to sorghum/cowpea (1.19) intercropping (Table 4 ), indicating $55 \%$ and $19 \%$ yield advantage respectively over sole crops. Though the yield of cowpea was higher than the Soybean in an intercropping system, the greater enhancement in sorghum yield intercropped with soybean was manifested by total higher LER of the system. The total LER in all cases was more than unity showing that intercropping of legumes with sorghum is 
Kinde Lamessa et al.,

advantageous in all instances rather than sole planting of sorghum. Higher LER in intercropping than sole cropping has also been reported in maize/soybean by Ullah et al. (2007). The yield advantage could be due to the efficient utilization of growth resources by the intercropped crops or the intercropping advantages of nitrogen fixation and increased light use efficiency (Willey, 1985; Reddy, 2000). Although, Yesuf ( 2003) reported that LER decreased with an increase in planting density, in this present experiment it was governed by time of planting of the legumes too. From this result, it can be concluded that additional yield can be produced by intercropping sorghum with a suitable legume at an appropriate time of planting and planting pattern. Sowing legume crops at first weeding of sorghum gave highest sorghum partial LER (0.763) and the least were obtained when sorghum was planted simultaneously with legumes (0.609). The highest sorghum partial LER $(0.765)$ and the least $(0.638)$ were obtained from $2 R$ and DAPs $+2 R$ planting pattern, respectively. Planting soybean and cowpea at first weeding of sorghum resulted in higher monetary value than planting soybean and cowpea simultaneously with sorghum. From all interaction effect when cowpea was intercropped at first weeding or hoeing sorghum in $2 \mathrm{R}$ planting pattern gave highest GMV (20561 ETB ha $\left.{ }^{-1}\right)$ and the lowest GMV(13264 ETB ha ${ }^{-1}$ ) was recorded when cowpea intercropped with sorghum simultaneously in DAPs planting pattern. GMV was higher in intercropping system than sole cropping systems (Table 6). This is was in agreement with the findings of Wondimu (2013) and Alice (2007) obtained higher monetary returns from intercropping than sole maize, in maize soybean cropping system. Similarly, by Biruk (2007) reported that intercropping sorghum with common bean was more advantageous than sole cropping of either common bean or sorghum.

\section{CONCLUSIONS}

The most important strategy to increase agricultural output is the development of new high intensity cropping system, including intercropping system, which is tolerant to biotic and abiotic stresses. Sorghum grain yield was significantly affected due to main effect legumes crop, time of planting and planting pattern. The highest sorghum yield was recorded when sorghum intercropped with soybean, legume crops intercropped at first hand weeding sorghum at $2 \mathrm{R}$ planting pattern. The interaction effect of legume, their planting time and planting pattern showed that planting of soybean in double alternate plants in between sorghum plants at the first weeding of sorghum resulted in a significant increase in sorghum yield over other interaction except the interaction of two soybean rows planted at the first weeding of sorghum in between two sorghum rows. Further, the latter interaction was statistically in parity with the interaction of two rows of cowpea planted at first weeding in sorghum. Simultaneous planting of double plants of cowpea in between the sorghum plants resulted in significant decrease in sorghum yield over other interactions. Partial and total LER of sorghum was highest when intercropped with soybean. On the other hand, interaction of planting time and planting pattern revealed highest LER when legumes were planted at first weeding in sorghum in double row intercropping. However, it was found to be statistically in parity with simultaneously planted legumes in double alternate plants within sorghum plants plus two rows of legumes in between the sorghum rows. Highest gross monetary benefit was accrued from planting two
Sci. Technol. Arts Res. J., July-Sep 2015, 4(3): 38-46

rows of cowpea with the first weeding of sorghum in between the two rows of sorghum. However, it was at par with simultaneous planting of cowpea in double alternate plants within sorghum plants along with two rows of cowpea in between sorghum rows and two rows of soybean planted in between two rows of sorghum at first weeding in sorghum. The following are recommended from the study. The result clearly depicted that the role of legumes in increasing production per unit area. Under these scenarios also intercropping gave high yield advantage over sole cropping. In area where livestock and sorghum is the main source monetary income for farmers intercropping cowpea and soybean at first weeding of sorghum in $2 \mathrm{R}$ planting pattern were recommended. Legumes crop soybean and cowpea should involved in sorghum cropping either simultaneously planting or sowing at first weeding or hoeing of sorghum.

\section{Conflict of Interest}

Conflict of interest none declared.

\section{Acknowledgments}

I would like to thank the Oromia Agricultural Research Institute (OARI) for financial support and Mechara Agricultural Research Center (MeARC) is acknowledged for facilitating for research work. My sincere thanks also go to Mr. Eshetu Ararso, Mr. Dadi Gudeta, Mr. Wandimu Bekele Mr. Muleta Debela, Mr. Desalegn Mamo, Mr. Asfaw Zewdu, Mr. Kasahun Regassa and all staff of Mechara Agricultural research center. Especial thanks go to Amado Usma'el for his support during sowing of the experiment and data collection.

\section{REFERENCES}

Addo-Quaye, A.A., Darkwa, A.A. and Olcoo, G.K. (2011). Growth analysis of component crops: In a maize/soybean intercropping system as affected by time of planting and spatial arrangement. ARPN Journal of Agricultural Biological Science 6(6): 34-44.

Alice, T. (2007). Adaptability of Soybean [Glycine max (L).Merr.)] Varieties to Intercropping under Leaf Stripped and Detasselled Maize (Zea mays L.). M.Sc Thesis Zimbabwe University.

Asfaw Adugna. (2007). The Role of Introduced Sorghum and Millets in Ethiopian Agriculture. Melkassa Agricultural Research Center. SAT eJournal 3(1): 1-4.

Biruk Tesfaye (2007). Effects of Planting Density and Varieties of Common bean (Phaseolus vulgaris L.) Intercropped with Sorghum (Sorghum bicolor L.) on Performance of the Component Crops and Productivity of the System in South Gondar, Ethiopia. M.Sc. Thesis. Haramaya University.

Champion, G.T., Froud-Williams, R.J. and Holland, J.M. (1998). Interactions between wheat cultivar, row spacing and density and the effect on weed suppression and crop yield. Department of Agricultural Botany, School of Plant Science. The University of Reading, UK.

Chemeda Fininsa. (1997). Effect of Planting Pattern, Relative Time of Planting Date and Intra- row Spacing of on a Haricot bean /Maize intercrop. African Crop Science Journal 5(1): 15-22. 
Kinde Lamessa et al.

CSA (Central Statistics Agency), 2012. Report on Area and Crop Production Forecast for Major Crops. Statistical Bulletin. V.505. Addis Ababa, Ethiopia.

Darshan, R., 2008. Intercropping of Pigeon pea with Sesame Cultivars under Different Planting Geometry and Row Proportions in Northern Transition Zone of Karnataka. M.Sc thesis, Department of Agronomy College of Agriculture, Dharwad University of Agricultural Sciences, India.

Egbe, O.M, S.E. Alibo and I. Nwueze, 2010. Evaluation of Some Extra-early- and Early- Maturing Cowpea Varieties for Intercropping with Maize in Southern Guinea Savanna of Nigeria. Agriculture and Biology Journal of North-America 1(5): 845-858

FAO (Food Agricultural Organization), 2012. The State of Food and Agriculture Rome, Italy.

FAO (Food and Agricultural Organization), (2000). Fertilizers and their use 4th ed. International fertilizer industry association (IFIA), FAO, Rome, Italy.

Fasil Reda and Verkleij, J.A.C. (2007). Cultural and Cropping Systems Approach for Striga Management a Low Cost Alternative Option in Subsistence farming pp 234-245. In: G Ejeta \& J Gressel (eds) Integrating New Technologies for Striga Control: towards ending the Witch-hunt World Scientific, Singapore.

Gomez, K.A. and Gomez, A.A. (1984). Statistical Procedures for Agricultural Research. $2^{\text {nd }}$ Edition. John Wiley and Sons Inc. Inter-Science Publications .New York. pp. 180-225.

Jensen, E.S. (1996). Grain Yield, Symbiotic N2 Fixation and Interspecific Competition for Inorganic $\mathrm{N}$ in Peabarley Intercrops. Plant and Soil 182: 25-38.

Langat, M.C., Okiror, M.A., Ouma, J.P. and Geimba, R.M. (2006). The Effect of Intercropping Groundnut (Arachis hypogaea L.) with sorghum [Sorghum bicolor L. Monech] on Yield and Cash Income. African Journal of Agricultural Research 2(12): 612-624.

McARC (Mechara Agricultural Research Center), (2010). Annual Research Report. Mechara Agricultural Research Center, Ethiopia.

McARC (Mechara Agricultural Research Center), (2013). Weather Data. Mechara Agricultural Research Center,

Murphy, H.F. (1968). A report on fertility status and other data on some soils of Ethiopia.Expt.Bull. No. 44. College of Agriculture, Haile Selasie I University, Alemaya, Ethiopia. 551p.

Myaka, F.A. and Kabissa, J.C.B. (1996). Fitting short duration cowpea into a cotton-based cropping system in Tanzania: effect of planting pattern, time of planting cowpea, and insecticide application to the cotton. Experimental Agriculture 32: 225-230.

Nnoko, E.N. and Doto, A.C. (1980). Intercropping maize or millet with soybean with particular reference to planting schedule. In: proceedings of the 2 Symposium. Intercropping in semi arid areas, Morogoro. 4-7 August. IDRC- public (Canada), pp 3336.
Sci. Technol. Arts Res. J., July-Sep 2015, 4(3): 38-46

Oseni, T.O. and Aliyu, I.G. (2010). Effect of Row Arrangements on Sorghum Cowpea Intercrops in the Semi-Arid Savannah of Nigeria. International Journal of Agriculture and Biology 12: 137-140.

Oseni, T.O. (2010). Evaluation of Sorghum/Cowpea Intercrop Productivity in Savanna Agro-Ecology using Competition Indices. Journal of Agricultural Science 2(3): 229-234.

Rana, R.S., Singh, B. and Negi, S.C. (2001). Management of Maize/Legume Intercropping under Mid-hill Sub-humid Conditions. Indian Journal Agricultural Research 35(2): 100-110.

Reddy, R.S. (2000). Principles of crop production. Kalyani Publishers, New Delhi-110002, India. Pp. 45-47.

Seran, T.H. and Brintha, I. (2010). Review on maize based intercropping. Journal of Agronomy 9(3): 135145.

Shetty, S.V.R., Ntare, B.R., Bationo, A. and Renard, C. (1995). Millet and cowpea in mixed farming systems of the Sahel: A review of strategies for increased productivity and sustainability. Pp.293-303. In: Livestock and sustainable nutrient cycling in mixed farming systems of sub-Saharan Africa. Volume 2: Technical Papers Proceedings, Addis Ababa, Ethiopia, 22- 26 November 1993.

Tamado, T. and Eshetu, M. (2002). Evaluation of Sorghum, Maize and Common bean cropping system in East Hararghe, Ethiopia. Ethiopian Journal Agricultural Science 17:33-37

Tekelign Tadesse (1991). Soil, plant, water, fertilizer, animal manure and compost analysis. Working Document No.13. International livestock Research Center for Africa (ILCA), Addis Ababa

Ullah, A., Bhatti, M.A., Gurmani, Z.A. and Imran, M. (2007). Studies on planting patterns of maize (Zea mays L.) facilitating legumes intercropping. Pakistan Journal of Agricultural Research 45(2):113-117.

Willey, R.W. (1979). Intercropping: its importance and research needs. Competition and yield advantages. Field Crops Research 32: 1-10.

Willey, R.W. (1985). Evaluation and presentation of intercropping advantages. Experimental Agriculture 21: 119-133.

Wondimu Bekele (2013). Evaluation of Soybean Varieties and N Fertilizer Rates on Yield, Yield Components and Productivity of Associated Crops under Maize/ Soybean Intercropping at Mechara, Eastern Ethiopia. M.Sc. Thesis. Haramaya University.

Yadav, R.L., Prasad, K. and Dwivedi, B.S. (1998). Cropping systems research. Pp. 193-213. In: R.L Yadav, P. Singh, and R. Prasad and I.P.S. Ahlawat (eds.). Fifty years of agronomic research in India. Indian Society of Agronomy, New Delhi, India.

Yesuf Mohammed (2003). Effect of Planting Arrangement and Population Densities of Haricot bean on Productivity of Sorghum/Haricot bean Additive Mixture. M.Sc. Thesis. Alemaya University. 